Хірургічна стоматологія

УДК 617.52-002.36-07-08

DOI 10.11603/2311-9624.2019.2.10397

(У. Д. Матолич, О. Я. Мокрик, С. В. Уштан, В. В. Винарчук-Патерега

Львівський національний медичний університет імені Данила Галицького

ulyanam23@gmail.com

\title{
Значення прокальцитоніну для оцінки тяжкості одонтогенних гнійно-запальних захворювань м'яких тканин щелепно-лицевої ділянки та як біомаркера ефективності лікування
}

Резюме. Одонтогенні запальні захворювання щелепно-лицевої ділянки посідають перше місце серед захворювань у клініці щелепно-лицевої хірургії. Кількість гнійних ускладнень, що виникають від запальних процесів, складає 6-40%. Успіх лікування пацієнтів із даною патологією залежить від ранньої діагностики, об’єктивної оцінки тяжкості стану, проведення персоніфікованої антибактеріальної терапії. Біомаркер прокальцитонін (ПКТ) відповідає концепції SMART: S - specific and sensitive (чутливим і специфічним), M - measurable (вимірюваним), A - available and affordable (доступним), $\mathrm{R}$ - responsive and reproducible (відтворюваним), T - timely (своєчасним). На даний час діагностична роль тесту ПКТ у комплексній оцінці перебігу одонтогенного запального процесу залишається недостатньо вивченою.

Мета дослідження - вивчити особливості змін рівня прокальцитоніну в сироватці крові при одонтогенних гнійно-запальних захворюваннях м’яких тканин щелепно-лицевої ділянки різної тяжкості та його ефективність при лікуванні.

Матеріали і методи. У дослідження включено 89 хворих із одонтогенною інфекцією щелепно-лицевої ділянки: 34 пацієнтів з одонтогенною інфекцією одного клітковинного простору (перша група), 35 - двох клітковинних просторів (друга група); 20 - трьох і більше клітковинних просторів (третя група). Визначення рівня ПКТ у сироватці крові виконували на 1-шу добу до проведення лікування, на 5-ту і 9-ту доби методом імуноферментного аналізу.

Результати досліджень та їх обговорення. В першій групі було виявлено невисоку концентрація ПКТ протягом усього періоду спостереження $(0,06 \pm 0,02)$ нг/мл. У другій групі на 1-шу добу рівень ПКТ був підвищеним $(1,15 \pm 0,5)$ нг/мл. У 26 \% хворих рівень ПКТ на 9-ту добу склав $(1,02 \pm 0,05)$ нг/мл, що в 17 разів вище від показників першої групи, p<0,05. Виявлене значення корелювало з тяжкістю патологічного процесу. В третій групі на 1-шу добу рівень ПКТ був вище від рівня першої групи в 43 рази, другої групи - 2,36 раза. Максимальні рівні ПКТ простежували у 35 \% пацієнтів третьої групи протягом усього спостереження: на 1-шу добу - $(3,23 \pm 0,19)$ нг/мл; 5-ту добу - $(3,14 \pm 0,05)$ нг/мл; 9-ту добу - $(2,82 \pm 0,04)$ нг/мл. У цих хворих не відмічалося достовірного зниження ПКТ. Їх стан оцінювали як середньої тяжкості, тяжкий.

Висновки. Рівень ПКТ $>1,5$ нг/мл у сироватці крові є свідченням подальшого розвитку гнійно-запального процесу, високого ризику виникнення ускладнень та вимагає оцінити ефективність антибактерійної терапії, що зумовлює додаткове втручання - ревізію вогнища запалення.

Ключові слова: гнійні запальні захворювання щелепно-лицевої ділянки; сироватковий прокальцитонін; ускладнення; моніторинг; лікування.

\section{(У. Д. Матолич, О. Я. Мокрик, С. В. Уштан, В. В. Винарчук-Патерега}

Львовский национальный медицинский университет имени Данила Галицкого

\section{Значение прокальцитонина для оценки тяжести одонтогенных гнойно-воспалительных заболеваний мягких тканей челюстно- лицевой области и как биомаркера эффективности лечения}

Резюме. Одонтогенные воспалительные заболевания челюстно-лицевой области занимают первое место среди заболеваний в клинике челюстно-лицевой хирургии. Количество осложнений, возникающих от воспалительных процессов, составляет 6-40 \%. Успех лечения пациентов с данной патологией зависит от ранней диагностики, объективной оценки тяжести состояния, проведения персонифицированной антибактериальной терапии. Биомаркер прокальцитонин (ПКТ) соответствует концепции 
SMART: S - specific and sensitive (чувствительным и специфическим), M - measurable (измеряемым), A - available and affordable (доступным), R - responsive and reproducible (воспроизводимым), T - timely (своевременным). В настоящее время диагностическая роль теста ПКТ в комплексной оценке течения одонтогенного воспалительного процесса остается недостаточно изученной.

Цель исследования - изучить особенности изменений уровня прокальцитонина в сыворотке крови при одонтогенных гнойно-воспалительных заболеваниях челюстно-лицевой области различной тяжести и его эффективность в лечении.

Материалы и методы. В исследование включено 89 больных с одонтогенной инфекцией челюстно-лицевой области: 34 пациентов с одонтогенной инфекцией одного клетчаточного пространства (первая группа), 35 - двух клетчаточных пространств (вторая группа) 20 - трех и более клетчаточных пространств (третья группа). Определение уровня ПКТ в сыворотке крови проводили на 1-е сутки до проведения лечения, на 5-е и 9-е сутки методом иммуноферментного анализа.

Результаты исследований и их обсуждение. В первой группе была обнаружена низкая концентрация ПКТ в течение всего периода наблюдения $(0,06 \pm 0,02) \mathrm{Hr} /$ мл. Во второй группе на 1-е сутки уровень ПКТ был повышенным $(1,15 \pm 0,5)$ нг/мл. У 26 \% больных уровень ПКТ на 9-е сутки составил $(1,02 \pm 0,05)$ нг/мл, что в 17 раз выше показателей первой группы, р<0,05. Обнаруженное значение коррелировало с тяжестью патологического процесса. В третьей группе на 1-е сутки уровень ПкТ был выше уровня первой группы в 43 раза, второй группы - 2,36 раза. Максимальные уровни ПКТ наблюдались у 35 \% пациентов третьей группы в течение всего наблюдения: на 1-е сутки - $(3,23 \pm 0,19)$ нг/мл; 5-е сутки - $(3,14 \pm 0,05)$ нг/мл; на 9-е сутки - $(2,82 \pm 0,04)$ нг/мл. У этих больных не отмечалось достоверного снижения ПКТ. Состояние больных оценивалось как средней тяжести, тяжелое.

Выводы. Уровень ПкТ>1,5 нг/мл в сыворотке крови свидетельствует о дальнейшем развитии гнойно-воспалительного процесса, высокого риска возникновения осложнений и требует оценить эффективность антибактериальной терапии, требует дополнительного вмешательства - ревизию очага воспаления.

Ключевые слова: гнойные воспалительные заболевания челюстно-лицевой области; сывороточный прокальцитонин; осложнения; мониторинг; лечение.

\section{CU. D. Matolych, O. Ja. Mokryk, S. V. Ushtan, V. V. Vynarchuk-Paterega}

Danylo Halytskyi Lviv National Medical University

\section{The importance of procalcitonin for assessing the severity of odontogenic purulent - inflammatory diseases of the soft tissues of the maxillofacial region and as a biomarker of treatment effectiveness}

Summary. Odontogenic inflammatory diseases of the maxillofacial area occupy the first place among the diseases in the clinic of maxillofacial surgery. The number of complications arising from inflammatory processes is $6-40 \%$. The success of treatment of patients with this pathology depends on early diagnosis, an objective assessment of the severity of the condition, the conduct of personified antibiotic therapy. The biomarker procalcitonin (PCT) is consistent with the SMART concept: $\mathrm{S}$ - specific and sensitive, $\mathrm{M}$ - measurable, $\mathrm{A}$ - available and affordable, $\mathrm{R}$ - responsive and reproducible, $\mathrm{T}$ - timely. At present, the diagnostic role of the PCT test in the comprehensive assessment of the odontogenic inflammatory process remains inadequate. The aim of the study - to learn the features of changes in the level of serum procalcitonin in case of odontogenic inflammatory diseases of the maxillofacial region of varying severity and its effectiveness in monitoring the treatment.

Materials and Methods. The study included 89 patients with odontogenic infections of the maxillofacial area: 34 patients with odontogenic infection of one cellular space (group I), 35 - two cellular spaces (group II); 20 - three or more cellular spaces (group III). Determination of the level of PCT in serum was performed 1 day before treatment, at 5 and 9 days with immunoassay.

Results and Discussion. In the group I, a low PCT concentration was detected throughout the observation period $(0.06 \pm 0.02) \mathrm{ng} / \mathrm{ml}$. In group II, for 1 day, the level of PCT was elevated $(1.15 \pm 0.5) \mathrm{ng} / \mathrm{ml}$. In $26 \%$ of patients, the level of PCT for the 9th day was $(1.02 \pm 0.05) \mathrm{ng} / \mathrm{ml}$, which is 17 times higher than that of group I, $\mathrm{p}<0.05$. The revealed value correlated with the severity of the pathological process. In the group III, for the first day, the level of PCT was 43 times higher than the level of group I, group II -2.36 times. Maximum PCT levels were observed in $35 \%$ of patients in group III during the entire observation: at day $1-(3.23 \pm 0.19) \mathrm{ng} /$ $\mathrm{ml} ; 5$ days - $(3.14 \pm 0.05) \mathrm{ng} / \mathrm{ml} ; 9$ days $-(2.82 \pm 0.04) \mathrm{ng} / \mathrm{ml}$. These patients did not notice a significant decrease in PCT. The condition of patients was assessed as moderate, severe. 


\section{Хірургічна стоматологія}

Conclusions. The level of PCT blood serum of $1.5 \mathrm{ng} / \mathrm{ml}$ is evidence of further development of purulentinflammatory process, high risk of complications and requires an assessment of the effectiveness of antibiotic therapy and causes additional intervention - an audit of the inflammatory cell.

Key words: inflammatory diseases of the maxillofacial area; serum procalcitonin; complications; monitoring; treatment.

Вступ. Запальні захворювання щелепнолицевої ділянки є найчастішою нозологією, яка буває в щелепно-лицевій хірургії (40-55 \%) $[1,2]$. В останні роки спостерігають не тільки зростання кількості хворих із гнійними запальними процесами, а й відзначають зміну клінічних проявів даної патології [3, 4]. Збільшилося число випадків затяжного перебігу запальних захворювань щелепно-лицевої локалізації, їх хронізації та розвитку місцевих і загальних ускладнень, які можуть призвести до серйозних і небезпечних для життя захворювань [5]. Кількість ускладнень, що виникають від запальних процесів, складає 6-40 \% [6]. Можна відзначити кілька факторів, що сприяють розвитку ускладнень: швидке поширення інфекції, індивідуальна сприйнятливість організму інфекційного агента, затримка в постановці діагнозу, неефективне лікування на тлі зміненої специфічної та неспецифічної резистентності організму.

Зусилля багатьох науковців спрямовані на пошук високоспецифічних, чутливих і доступних маркерів, що дозволять лікарю провести точну і своєчасну діагностику, швидко прийняти рішення та провести моніторинг ефективності лікування [7, 8]. Бажаний показник повинен максимально відповідати властивостям «ідеального» біомаркера. Одним із таких маркерів є прокальцитонін (ПКТ), так як відповідає концепції SMART: S - specific and sensitive (чутливий і специфічний), M measurable (вимірюваний), A - available and affordable (доступний), $\mathrm{R}$ - responsive and reproducible (відтворюваний), T - timely (своєчасний). Велика кількість публікацій демонструє поступове використання тесту на ПКТ у сучасній клінічній практиці [9-11]. ПКТ - це попередник гормону кальцитоніну, який не проявляє гормональної активності й виробляється при запаленні [12]. Доведено, що підвищення рівня ПКТ у сироватці крові відбувається під дією ендотоксинів бактерій і корелює з тяжкістю інфекції $[13,14]$. Завдяки швидкій імунній відповіді рівень ПКТ зростає вже через 6-12 год після початку запального процесу $[15,16]$.
Важливим аспектом профілактики ускладнень є раціональне застосування антибіотиків. Необгрунтоване призначення антибіотиків призводить до бактеріальної стійкості. У цих умовах необхідний динамічний аналіз вмісту біомаркера ПКТ [17]. Діагностична роль тесту ПКТ у комплексній оцінці перебігу одонтогенного гнійно-запального процесу залишається недостатньо вивченою. Таким чином, визначення рівня ПКТ у сироватці крові дозволить оцінити активність запального процесу, спрогнозувати розвиток ускладнень, провести корекцію медикаментозного лікування.

Метою дослідження було вивчити особливості змін рівня прокальцитоніну в сироватці крові при одонтогенних гнійно-запальних захворюваннях м'яких тканин щелепно-лицевої ділянки різної тяжкості та його ефективність при лікуванні.

Матеріали і методи. Визначення ПКТ у сироватці крові виконували на 1-шу добу до проведення лікування, на 5-ту і 9-ту доби методом імуноферментного аналізу із застосуванням наборів реагентів фірми «Diaclone» (Франція). У дослідження було включено 89 хворих: 34 пацієнтів із одонтогенною флегмоною одного клітковинного простору (перша група), 35 - флегмоною двох клітковинних просторів (друга група); 20 - флегмоною трьох і більше клітковинних просторів (третя група). Оцінку параметрів проводили відносно встановлених норм (норма ПКТ у сироватці крові $(0,02 \pm 0,002) \mathrm{Hг} / \mathrm{Mл})$ [12].

Діагноз встановлювали на основі аналізу об'єктивних даних, результатів загальноклінічних методів дослідження. Комплексне лікування хворих полягало у хірургічному розкритті вогнищ гнійного запалення, дренуванні післяопераційних ран, видаленні зуба, застосуванні антибактеріальної, протизапальної, дезінтоксикаційної терапій. Статистичну обробку даних виконували 3 використанням програми Statistica 6.1 і пакета прикладних програм Excel 2013.

Результати досліджень та їх обговорення. У хворих першої групи встановили невисоку 
концентрацію ПКТ протягом усього періоду спостереження - $(0,06 \pm 0,02) \mathrm{Hг} /$ мл. Імовірним медіатором, що стимулює продукцію ПКТ в організмі, є ліпополісахарид бактерійної стінки мікроорганізмів. Відсутність збільшення концентрації ПКТ у крові свідчить про те, що при одонтогенній флегмоні одного клітковинного простору не відбувається масивного виділення в кров ліпополісахаридів, а також про відсутність генералізованої бактерійної інфекції.

ПКТ на 1-шу добу в другій групі був підвищений у $100 \%$ хворих і склав $(1,14 \pm 0,5) \mathrm{нг} /$ мл. Надалі спостерігали достовірне поступове зниження рівня ПКТ: $(1,21 \pm 0,01) \mathrm{Hг} /$ мл на - 5-ту добу і $(0,54 \pm 0,03)$ нг/мл на - 9-ту добу. Згідно 3 результатами тесту на ПКТ, на 1-шу добу хворих другої групи поділили на дві підгрупи: перша - рівень біомаркера >1,5 нг/мл (26\% осіб); друга - $\leq 1,5$ нг/мл (74 \% хворих), що корелювало з тяжкістю патологічного процесу. На 5-ту добу рівень ПКТ в першій підгрупі незначно зменшився - $(1,66 \pm 0,03)$ нг/мл, на 9-ту добу склав $(1,02 \pm 0,05)$ нг/мл, що було в 52 рази достовірно більшим від норми і в 17 разів від показників першої групи, $p<0,05$. У другій підгрупі нормалізацію рівня ПКТ спостерігали на 9-ту добу $(0,07 \pm 0,02)$ нг/мл на тлі стихання гнійно-запального процесу, $\mathrm{p}<0,05$. У процесі спостереження у хворих другої підгрупи виявлялись клінічні ознаки одужання. Пацієнти 3 рівнем ПКТ вище 1,5 нг/мл до лікування вимагають динамічного спостереження та за потреби - проведення корекції лікування.

У третій групі рівень ПКТ був вище від рівня першої групи в 43 рази, другої групи - в 2,36 раза. Виходячи від початкового рівня ПКТ, на 1-шу добу хворих третьої групи поділили на дві підгруп: перша ->1,5 нг/мл (35 \% осіб); друга $-\leq 1,5$ нг/мЛ (65 \% хворих). Максимальні рівні ПКТ спостерігали у пацієнтів першої підгрупи протягом усього спостереження: на 1-шу добу - $(3,23 \pm 0,1)$ нг/мл; на 5-ту добу - $(3,14 \pm 0,05)$ нг/мл; на 9-ту добу - $(2,82 \pm 0,04)$ нг/мл. Стан хворих оцінювали як середньої тяжкості, тяжкий. Це свідчить про подальший розвиток гнійнозапального процесу, несприятливий прогноз, вимагає призначати антибіотики останніх поколінь і провести повторне хірургічне втручання 3 метою розкриття перифокальний скупчень гною. На 9-ту добу дослідження рівень ПКТ у другій підгрупі достовірно знизився від рівня в 1,8 раза порівняно 3 1-ю добою (5 доба - $(1,12 \pm 0,45)$ нг/мл; 9 доба - $(1,04 \pm 0,24) \mathrm{нг} /$ мл; $\mathbf{p}<0,05)$. Індивідуальний моніторинг скарг та об'єктивних даних пацієнтів друга підгрупи в динаміці продемонстрував зменшення вираження запальної відповіді. Отже, рівень вище 1,5 нг/мл є свідченням імовірності бактерійної активності та переходу захворювання в затяжний період реконвалесценціії.

Ми вважаємо ПКТ високочутливим і специфічним маркером запальної реакції при гнійно-запальних захворюваннях щелепнолицевої ділянки, за допомогою якого можна провести оцінку тяжкості стану хворого, моніторинг ефективності лікування в реальному проміжку часу, спрогнозувати появу нових інфекційних вогнищ.

Визначення концентрації ПКТ є своєчасним і надійним тестом, що дозволяє клініцистам пришвидшити час діагностики i, по суті, - проводити «лікування з відкритими очима» (результат через 2-2,5 год). Метод визначення ПКТ (імуноферментний аналіз) є простим і недороговартісним, результати - надійними та можна використовувати для диференціації та моніторингу захворювання (концепція SMART).

Висновки. Встановлено, що тест на визначення рівня ПКТ у сироватці крові пацієнтів із одонтогенною інфекцією має високу інформативність як метод для виявлення або виключення виникнення ускладнень запальних процесів у щелепно-лицевій ділянці, визначення ефективності хірургічного лікування та може бути основою для проведення персиніфікованого антибактерійного лікування: призначення і тривалості застосування або відмови антибіотиків. Проведена оцінка клінічної значимості визначення ПКТ у моніторуванні тяжкості перебігу та ранній діагностиці ускладнень показала, що за рівнем ПКТ $>1,5$ нг/мл на початку лікування можна з високим ступенем достовірності спрогнозувати розвиток ускладнень перш ніж з'являться будь-які клінічні симптоми та дозволяє оцінити ефективність антибактерійної терапії. 


\section{Хірургічна стоматологія}

\section{Список літератури}

1. Pattern of odontogenic infections at a tertiary hospital in Tehran, Iran: A 10-year retrospective study of 310 patients / F. Pourdanesh, N. Dehghani, M. Azarsina, Z. Malekhosein // Journal of dentistry. - 2013. - Vol. 10. - P. 319-328.

2. Slavkin H. Relationship of dental and oral pathology to systemic illness / H. Slavkin, B. Baum // J. Am. Med. Assoc. - 2012. - Vol. 284, No. 10. - P. 1215-1217.

3. Матолич У. Д. Динаміка зміни інтегральних індексів інтоксикації у хворих на флегмони та абсцеси щелепно-лицевої ділянки / У. Д. Матолич // Лікарська справа. - 2016. - № 1-2. - С. 97-101.

4. Куонг Ву Вьет. Современный взгляд на этиологию и патогенез одонтогенных абцессов и флегмон челюстно-лицевой области / Ву Вьет Куонг, Д. С. Аветиков, С. Б. Кравченко // Вісник проблем біології і медицини. - 2014. - № 1(2). - С. 79-83.

5. Pappa H. Mediastinitis from odontogenic infection. A case report. / H. Pappa, D.C. Jones // British Dental Journal. - 2005. - Vol. 198, No. 9. - P. 547-548.

6. Харьков Л. В. Ускладнення лікування запальних захворювань тканин щелепно-лицевої ділянки у дітей. Причини та їх профілактика / Л. В. Харьков, Л. М. Яковенко, І. Л. Чехова // Современная стоматология. - 2016. - № 5. - С. 48-52.

7. Матвійчук О. Б. Біомаркери запалення при третинному перитоніті / О. Б. Матвійчук // Український журнал хірургії. - 2017. - № 2 (33). - С. 37-40.

8. Procalcitonin-guided use of antibiotics for lower respiratory tract infection / D. T. Huang, D. M. Yealy, M. R. Filbin [et al.] // New England Journal of Medicine. - 2018. - Vol. 379, No. 3. - P. 236-249.

9. Procalcitonin as a marker for postoperative complications / C. Haane, W. A. Mardin, S. Irmscher N. Senninger, C. Schleicher, S. T. Mees // Clinical Laboratory. - 2010. - Vol. 56, No. 3-4. - P. 153-155.

\section{References}

1. Pourdanesh, F., Dehghani, N., \& Azarsina, M. (2013) Pattern of odontogenic infections at a tertiary hospital in Tehran, Iran: A 10-year retrospective study of 310 patients. Journal of Dentistry, 10, 319-328.

2. Slavkin, H., \& Baum, B. (2000). Relationship of dental and oral pathology to systemic illness. J. Am. Med. Assoc., 284, 1215-1217.

3. Matolych, U.D. (2016). Dynamika zminy intehralnykh indeksiv intoksykatsii u khvorykh na flehmony ta abstsesy shchelepno-lytsevoi dilianky [The dynamics of change of the integraled indexes of intoxication in patients with phlegmons and abscesses of the maxillofacial area. Likarska sprava-Medical Business, 1-2, 97-101 [in Ukrainian].

4. Cuong, Vu Viet, Avetikov, D.S., \& Kravchenko, S.B. (2014). Sovremennyy vzglyad na etiologiyu i patogenez odontogennykh abtsessov i flegmon chelyustno-litsevoy oblasti [Modern view of the etiology and pathogenesis of odontogenic abscesses and phlegmon maxillofacial region]. Visnyk Problem Biolohii i Medytsyny - Bulletin of Problems Biology and Medicine, 2, (1), 79-83 [in Russian]. 5. Pappa, H., \& Jones, D.C. (2005). Mediastinitis from odontogenic infection. A case report. British Dental
10. Mehanic S. The importance of serum procalcitonin in diagnosis and treatment of serious bacterial infections and sepsis / S. Mehanic, R. Baljic // Materia Socio-Medica. - 2013. - Vol. 25, No. 4. - P. 277-281.

11. Biomarkers in inflammatory bowel diseases: insight into diagnosis, prognosis and treatment / M. Norouzinia, V. Chaleshi, A. H. M. Alizadeh, M. R. Zali // Gastroenterol. Hepatol. Bed Bench. - 2017. - Vol. 10, No. 3. - P. 155-167. 12. Procalcitonin and the calcitonin gene family of peptides in inflammation, infection, and sepsis: a journey from calcitonin back to its precursors / K. L. Becker, E. S. Nylen, J. C. White [et al.] // The Journal of Clinical Endocrinology \& Metabolism. - 2004. - Vol. 89, No. 4. - P. 1512-1525.

13. Procalcitonin as biomarker of infection: Implications for evaluation and treatment / Falcao Gonçalves, Menezes Falcao, Duque Pinheiro // American Journal of Therapeutics. - 2017. - Vol. 24, No. 3 - P. 243-249.

14. Hatzistilianou M. Diagnostic and prognostic role of procalcitonin in infections / M. Hatzistilianou // The Scientific World Journal. - 2010. - No. 10. - P. 1941-1946. 15. Bremmer D. N. Acute exacerbations of chronic obstructive pulmonary disease with a low procalcitonin concentration: Impact of antibiotic therapy / D. N. Bremmer // Clin. Infect. Dis. - 2019. - No. 68. P. 725-729.

16. Березняков В. И. Содержание прокальцитонина и галектина-3 в крови больных с внебольничной пневмонией с сопутствующей хронической сердечной недостаточностью и без нее / В. И. Березняков, А. Н. Корж // Международный медицинский журнал. - 2015. - Т. 21, № 4. - С. 13-16.

17. Schuetz P. Procalcitonin for diagnosis of infection and guide to antibiotic decisions: past, present and future / P. Schuetz, W. Albrich, B. Mueller // BMC Medicine. - 2011. - No. 9. - P. 107-115.

\section{Journal, 198 (9), 547-548.}

6. Kharkov, L., Yakovenko, L., \& Chekhova, I. (2016). Uskladnennia likuvannia zapalnykh zakhvoriuvan tkanyn shchelepno-lytsevoi dilianky u ditei. Prychyny ta yikh profilaktyka [Complications of treatment of inflammatory diseases of tissues maxillo-facial region in children. Causes and prevention]. Sovremennaya stomatologiya - Modern Stomatology, 5, 48-52 [in Ukrainian].

7. Matviichuk, O.B. (2017). Biomarkery zapalennia pry tretynnomu perytoniti [Biomarkers of inflammatory in tertiary peritonitis]. Ukrainskyi zhurnal khirurhii Ukrainian Journal of Surgery, 2 (33), 37-40 [in Ukrainian]. 8. Huang, D.T., Yealy, D.M., \& Filbin, M.R. (2018) Procalcitonin-guided use of antibiotics for lower respiratory tract infection. New England Journal of Medicine, 379 (3), 236-249.

9. Haane, C., Mardin, W.A., \& Irmscher, S. (2010) Procalcitonin as a marker for postoperative complications. Clinical Laboratory, 56 (3-4), 153-155.

10. Mehanic, S., \& Baljic R. (2013). The importance of serum procalcitonin in diagnosis and treatment of serious bacterial infections and sepsis. Materia 
Sociomedica, 25, (4), 277-281.

11. Norouzinia, M., Chaleshi, V., \& Alizadeh, A.H.M. (2017). Biomarkers in inflammatory bowel diseases: insight into diagnosis, prognosis and treatment. Gastroenterol. Hepatol. Bed. Bench, 10, (3), 155-167.

12. Becker, K.L., Nylen, E.S., \& White, J.C. (2004). Procalcitonin and the calcitonin gene family of peptides in inflammation, infection, and sepsis: a journey from calcitonin back to its precursors The Journal of Clinical Endocrinology \& Metabolism, 89, (4), 1512-1525.

13. Falcao, Goncalves, Menezes, Falcao, \& Duque, Pinheiro (2017). Procalcitonin as biomarker of infection: Implications for evaluation and treatment. American Journal of Therapeutics, 24, (3), 243-249.

14. Hatzistilianou, M. (2010). Diagnostic and prognostic role of procalcitonin in infections. The Scientific World Journal, 10, 1941-1946.
15. Bremmer, D.N. (2019). Acute exacerbations of chronic obstructive pulmonary disease with a low procalcitonin concentration: Impact of antibiotic therapy. Clin. Infect. Dis., 68, 725-729.

16. Berezniakov, V.I., Korzh, O.M. (2015). Soderzhaniye prokaltsitonina i galektina-3 v krovi bolnykh s vnebolnichnoy pnevmoniyey $\mathrm{s}$ soputstvuyushchey khronicheskoy serdechnoy nedostatochnostyu i bez nee [The content of procalcitonin and galectin-3 in the blood of patients with community-acquired pneumonia and concomitant chronic heart failure and without]. Mezhdunarodnyy meditsinskiy zhurnal - International Medical Journal, 21 (4), 13-16 [in Russian].

17. Schuetz, P., Albrich, W., \& Mueller, B. (2011). Procalcitonin for diagnosis of infection and guide to antibiotic decisions: past, present and future. $B M C$ Medicine, 9, 107-115.

Отримано 10.05.19 